\title{
Influence of the Lactation Number on the Somatic Cell Count and Morphological Characterization of Cell Population in Cow Milk
}

\author{
Alexandra TĂBĂRAN ${ }^{1 *}$, Marian MIHAIU ${ }^{1}$, Sorin Daniel DAN ${ }^{1}$, Flaviu TĂBĂRAN ${ }^{1}$, Oana REGET ${ }^{1}$, Ionut \\ Vlad CORDIŞ ${ }^{1}$, Darius CORDEA ${ }^{1}$ \\ ${ }^{1}$ Department of Animal Breeding and Food Safety, University of Agricultural Sciences and Veterinary \\ Medicine, Cluj-Napoca, Romania; \\ *Corresponding author: lapusan_alexandra@yahoo.com
}

Bulletin UASVM Veterinary Medicine 72(2) / 2015,

Print ISSN 1843-5270; Electronic ISSN 1843-5378

DOI:10.15835/buasvmcn-vm: 11446

\begin{abstract}
The aim of this study was to evaluate the dynamics of the somatic cell count in cow's milk according to stage of lactation and season and to morphologically characterize the cell population in order to correlate it with the automated somatic cell count exam. Of the total milk samples, $26,66 \%$ were non-compliant milk samples reported to the EU standards. The dynamic evolution of the parameter for the survey period of 6 lactations in somatic cell count (SCC) showed a uniform increase, the milk being classified in the acceptable category only in the first five lactations. It was found that during the productive life the percentage of the milk samples classified as Class I $(<200000$ cells / ml) and II (200001-400000 cells / $\mathrm{ml})$ is characterized by a descending trend in quality associated with a significant increase of those classified as quality class III (under 1000000 cells / ml) and IV (1000000 cells / $\mathrm{ml}$ ). The highest influence on the milk cell population belongs to milk from cows with chronic mastitis, due to the fact that it does not show sensorial alterations. Another influence is the lactation number; cows found in advanced stages $(>5)$ showed a higher SCC than the maximum allowed limit. The morphological study of the cells has revealed the possibility to identify accurately and precisely the health state (hygiene quality) of the product destined for consumption.
\end{abstract}

Keywords: cytomorphological, mastitis, milk, SCC

\section{INTRODUCTION}

Milk is a biological product that contains a large number of constituents important for human health (Davis et al., 1983). The somatic cell count (SCC) is one of the most important parameters used to assess the hygiene state of milk as well as its quality for processing. The SCC term includes all types of cells and it is a reliable indicator of the immunological activity of the mammary gland and health state of the udder. Each cell type holds its own specific function during an immune response, therefore the distribution reflects the immunological status of the mammary gland
(Fetrow et al.,2000; Halasa et al.,2007; Geary et al., 2012).

The number of somatic cells found in milk is relevant for quality assessment but it is also essential to correlate it with a cytomorphological examination, by which any kind of health status alteration can be detected more efficiently. It was revealed that milk from healthy udders with a very low somatic cell count normally has a higher amount of lymphocytes and low amounts of macrophages and polymorphonuclears. There are not many detailed studies concerning the numerical variations within the somatic cell 
count according to the number of lactation and cytomorphological assessment, a large number of authors preferring automatic counting as the only method of evaluation.

Practical rapid methods to evaluate SCC are desired to monitor infections in early lactation. It is a proven fact that milk SCC are higher immediately after calving in both uninfected or infected quarters of the udder (Ruegg and Pantoja, 2013). Milk SCC shows a relatively rapid decrease over time after parturition, especially in those quarters that are uninfected (Brooks et al.,1982; Barkema, 1998). Earlier studies have shown that the SCC remains elevated in early lactation for a period of 5 to 35 days (Reichmuth, 1975; Sheldrake et al., 1983).

The variations in SCC are important and their analysis requires further development in order to fully understand the health status of the udder but also the possible risk for the consumers' health. Normally, somatic cell count from healthy, noninfected glands should be lower than 200,000 cells/ $\mathrm{ml}$ and a SCC between 200,000 and 300,000 cells/ $\mathrm{ml}$ is indicative of a degree of infection or initial stages of infection or diminished general udder health (Dohoo, 1993), or may raise suspicions of infectious mastitis in the cow (Smith, 2006). The maximum allowed limit set by the UE standards is 400.000 cells $/ \mathrm{ml}$. Although some countries have milk SCC legal limits above the EU standard of 400,000 cells $/ \mathrm{ml}$, almost all milk purchasing standards require a milk production below the EU upper threshold.

Given the importance of this quality parameter (SCC) for a safe production, our study aimed to assess the level of SCC depending on the lactation number and evaluate the relevance of an additional cytomorphological exam to the automatic testing that is currently performed.

\section{MATERIALS AND METHODS}

\section{Sample collection and preparation}

The research material was represented by 60 individual samples, collected from March 2015 May 2015 from dairy cow farms located in Cluj county. The samples were collected by groups, each group being in different stages of lactation and the cows aged between 3-14 years. These groups were formed as following:

Group I - 10 dairy cows found in the I $^{\text {st }}$ lactation; Group II - 10 dairy cows found in II ${ }^{\text {nd }}$ lactation; Group III - 10 dairy cows found in the III ${ }^{\text {rd }}$ lactation;
Group IV - 10 dairy cows found in the IV ${ }^{\text {th }}$ lactation; Group V - 10 dairy cows found in the $V^{\text {th }}$ lactation; Group VI - 10 dairy cows found in the VI ${ }^{\text {th }}$ lactation;

The collection of the samples was preceded by a preparation of the udder by washing. The first drops of milk were rejected in order to avoid the spreading of the pathogens. We also mention that in the tested farms the milking was done mechanically, followed by the immediate cooling of the milk at $2-4{ }^{\circ} \mathrm{C}$.

\section{Automatic detection of SCC}

The electronic device used for the determination of the SCC was a Fossomatic ${ }^{\mathrm{TC}} \mathrm{FC}$ (Foss, Germany). This device can be defined as a continuously operating fluorescent automatic microscope. Milk in contact with a specific dye forms a fluorescent complex, consequently to the attachment of the dye to the cell DNA. After staining, milk is presented under the form of a film of approximately $10 \mu \mathrm{m}$ thickness, on the surface of a rotate disk. Each nucleus is excited by the light of a xenon lamp at a certain wave length, generating a red light. This light is captured by the microscope each time a nucleus passes under the objective. These wavelengths are transformed into electrical signals, allowing them to be counted.

\section{The lactocytogram}

The cytomorphological exam was made using the milk cytogram method. Briefly, we centrifuged $10 \mathrm{ml}$ of each sample and from the sediment we collected the somatic cell deposit using a loop and spread it on a slide. The resulting smear was stained using the Diff-Quick staining technique.

\section{RESULTS AND DISCUSSION}

The EU legislation specifies limits regarding the number of somatic cells for cow milk, which is maximum 400.000 cells $/ \mathrm{ml}$ (Reg. 853/2004), while the US have set a maximum limit of 750.000 cells $/ \mathrm{ml}$. In order to classify milk quality according to SCC we established four hygiene quality classes as follows:

Class I, compliant milk, very good quality, with SCC $<200.000$ cells $/ \mathrm{ml}$

Class II, compliant milk, good quality, SCC between 200.000 and 400.000 cells $/ \mathrm{ml}$;

Class III, improper milk, acceptable quality only for marketing the products within Romania, SCC $<400.000-1.000 .000$ cells $/ \mathrm{ml}$

Class IV, non-compliant milk, SCC $>1.000 .000$ cells $/ \mathrm{ml}$ 
Following the statistical analysis of the samples for each SCC according to lactation period, we found that the lowest values were obtained as expected in the milk collected from first lactation cows, respectively $122.063 \pm 69.768 \mathrm{cells} / \mathrm{ml}$, and the highest values in the $\mathrm{VI}^{\text {th }}$ lactation, with an average of $627710 \pm 605949$ cells $/ \mathrm{ml}$. The variation coefficient showed low values within the entire period of sampling, which suggests that the SCC parameter was determined accordingly. We can state thatthe lactation number has a specific influence on the SCC and that it can be a good variation factor. Moreover, the correlation between the cell level obtained at the first lactation and the levels in the following lactations, can constitute a useful criterion for the assessment of the milking efficiency and hygiene status. The number of cells in the milk of each cow can constitute the objective of periodic monitoring data, which allows us to establish the incidence of mastitis within the population, a better follow-up and a more efficient therapy. The fact that the somatic cell level in milk collected during the first lactation is low and the increase is seen only starting with the II $^{\text {nd }}$ lactationmight lead to the idea that the preventive measures taken on a farm level during the exploitation of cows are inefficient.

Our results are in accordance with the ones published by Węglarz et al. (2008), which indicated the fact that the SCC increases along with age, stage of lactation, but these alterations are considered physiological only in the case of healthy cows. When an inflammatory disease occurs, the count is much higher (Węglarz et al., 2008). Following the milk cytogram testing we saw that more than $85 \%$ of the variations in SCC were not determined by the presence of inflammatory affections of the udder. Thus, we observed a progressive increase of the geometrical average of the number of cells in milk from the first lactation (105810 cells $/ \mathrm{ml}$ ) up to the sixth lactation (514380 cells/ml). The shift in dynamics of the SCC parameter for the 6 lactations is characterized by a uniform increase starting with lactation I until lactation IV, followed by a decrease in lactation $V$ and again an increase in lactation VI. We found that the average values of the SCC were below the maximum limit $(400000$ cells $/ \mathrm{ml}$ ) only in the first three lactations.

The cytomorphological exam also revealed a relatively high number of cells, with the polymorphonuclears that showed a phagocytosis process (Fig. 2, 4) being predominant. Among the microbial forms we found mainly cocci, under the form of staphylo and diplo - cocci.

Based on the cytological examination we classified the 60 analyzed samples from the standpoint of hygiene quality in the following categories:

- Milk from cows with exudative inflammatory affections (acute mastitis), clinically expressed (13.33\%);

- Milk from healthy cows presenting exudative inflammatory processes of the mammary gland, with no clinical expression (chronic mastitis) (28.33);

- Milk from clinically healthy cows, without inflammatory processes of the mammary gland but microbially contaminated (16.66\%);

- Milk from clinically healthy cows (41.66\%), without inflammatory processes of the mammary gland, obtained and processed in good hygienic conditions.

In the case of healthy milk and processed in good hygienic conditions, the milk sediment was obtained in very low quantities, sometimes barely visible. At the cytomorphological exam the smear

Tab. 1. The evolution in the SCC according to the number of lactations

\begin{tabular}{ccccccc}
\hline Lactation & No. sample & $\begin{array}{c}\text { SCC } \\
\text { average } \\
\text { (cell/ml) }\end{array}$ & $\begin{array}{c}\text { Standard } \\
\text { deviation } \\
\text { (SD } \pm \text { ) }\end{array}$ & Variation coeff. & $\begin{array}{c}\text { Min. SCC value } \\
\text { (cell/ml) }\end{array}$ & $\begin{array}{c}\text { Max. SCC value } \\
\text { (cell/ml) }\end{array}$ \\
\hline I & 10 & 122063 & 69768.1 & 0.57 & 53900 & 246000 \\
\hline II & 10 & 500100 & 666816.05 & 1.33 & 124000 & 2347000 \\
\hline III & 10 & 520300 & 617362.6 & 1.18 & 6000 & 2094000 \\
\hline IV & 10 & 686100 & 824640.4 & 1.20 & 194000 & 2878000 \\
\hline V & 10 & 545000 & 304976.5 & 0.55 & 139000 & 1031000 \\
\hline VI & 10 & 627710 & 605949.1 & 0.96 & 385000 & 2348000 \\
\hline
\end{tabular}


contained dispersed, scarce cells, in groups of 2-3, consisting of activated macrophages and late stage polymorphonuclears.

Along with the counting methods for somatic cells, the cytological diagnosis by lacto sediment technique can constitute a useful diagnosis method for surveillance of the hygienic quality and also the health status of milk available for consumption. The corroboration of the lactocytogram with the counting techniques has a lot of advantages, such as the possibility to differentiate between mastitis milk and colostrum or late stage milk, the

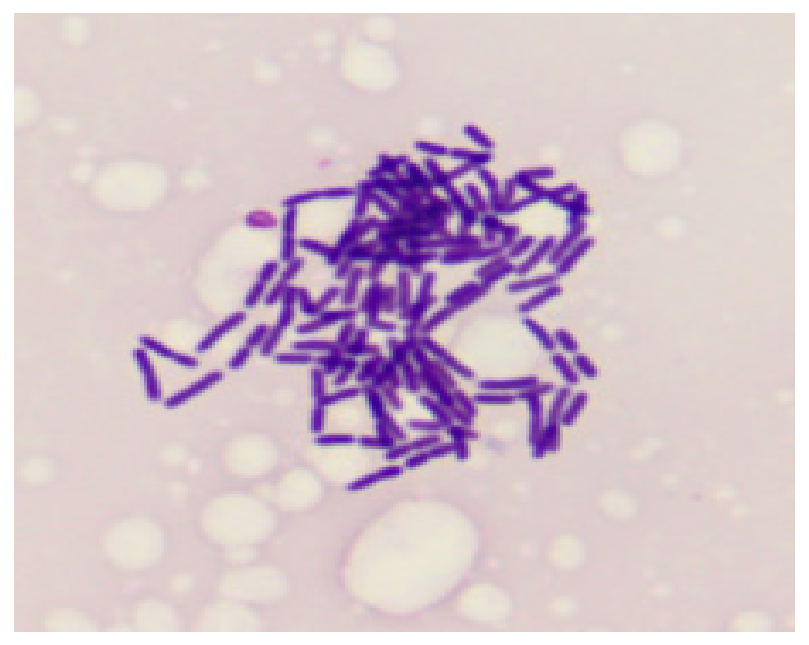

Fig.1. Microflora represented by bacilli groups bacili (Lactobacilli) (x100); Sample from the $\mathrm{I}^{\text {st }}$ lactation

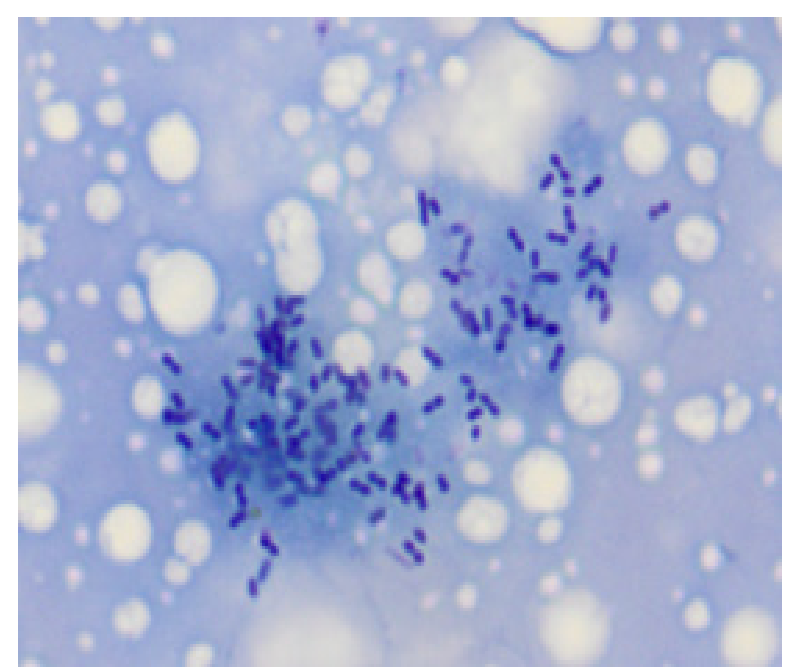

Fig. 3. Bacterial flora represented by cocci in diplo and staphylo arrangements (x100); Samples from the III ${ }^{\text {rd }}$ lactation possibility to identify microbially contaminated milk and, last but not least, identify milk obtained in more or less hygienic conditions. Correlating the results of somatic cell counting with the cytological exam we found that of the total amount of samples, $43.38 \%$ were negatively correlated.

\section{CONCLUSION}

The cytological examination combined with the automatic counting of somatic cells is strongly required due to the fact that it can identify the milk from chronic mastitis udders which is otherwise

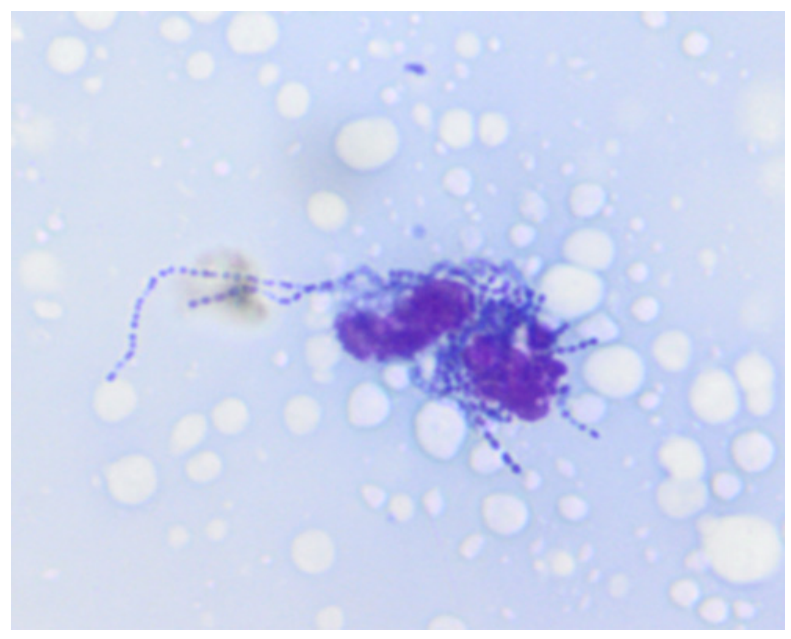

Fig.2. Neutrophils, bacterial flora represented by cocci disposed in chains, phagocytosis process ( $\mathrm{x} 100)$; Samples from the II $^{\text {nd }}$ lactation

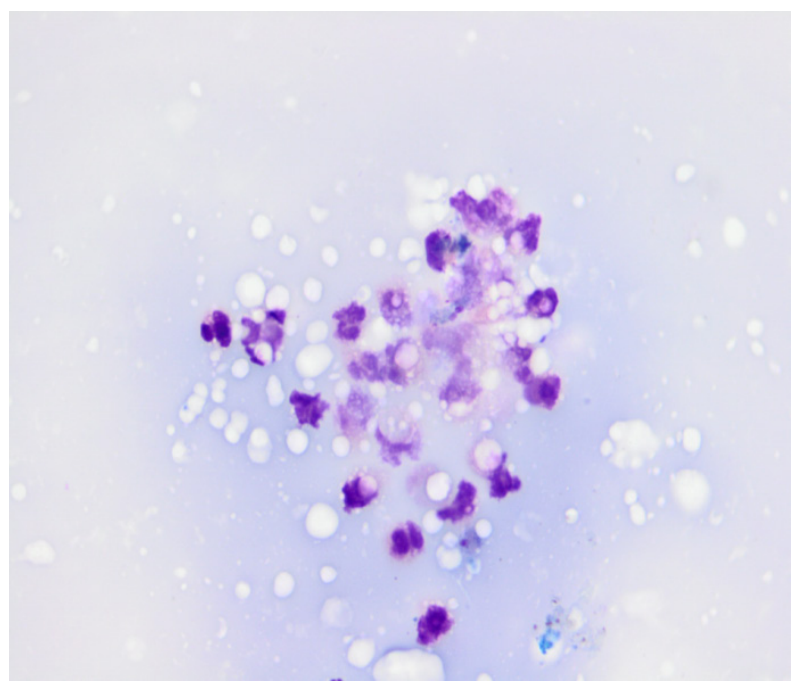

Fig. 4. Neutrophils and phagocytosis process (x100); Sample from the $\mathrm{V}^{\text {th }}$ lactation 
difficult to diagnose, given the fact that there are no sensory alterations. The configuration of cell population was represented mainly by filtration cells, polymorphonuclears, lymphocytes, macrophages in different stages of activation and respectively, epithelial cells. Considering the results of this study, we recommend the periodic health monitoring of the mammary gland by determining the SCC not only in bulk tank milk but also in individually collected samples. We also recommend the exploitation of cows for 4-5 lactations, given the increase of SCC after the IV ${ }^{\text {th }}$ lactation.

Acknowledgments. This paper was published under the frame of the Applicative partnership projects, PCCA no.153/2014

\section{REFERENCES}

1. Barkema HW, Deluyker H, Schukken YH, Lam TJGM (1999). Quarter milk somatic cell count at calving and at the first six milkings after calving. Prev Vet Med 38:1-9.

2. Brooks BW, Barnum DA, Meek AH (1982). A survey of mastitis in selected Ontario dairy herds. Can Vet J 23:156159.

3. Dohoo IR (1993). An evaluation of the validity of individual cow somatic cell counts from cows in early lactation. Prev Vet Med 16:103-110.
4. Fetrow J, Steward S, Eicker SS, Farnsworth R, Bey R (2000). Mastitis: an economic consideration. Proceedings of the 39th Annual Conference of the National Mastitis Council, Atlanta, GA, USA, 3-47.

5. Geary U, Lopez-Villalobos N, Begley N, McCoy F, O’Brien B, O'Grady L, Shalloo L (2012). Estimating the effect of mastitis on the profitability of Irish dairy farms. Journal of Dairy Science 95: 3662-3673.

6. Halasa T, Huijps K, Osteras O, Hogeveen H (2007). Economic effects of bovine mastitis and mastitis management: A review. Vet Quarterly 29:18-31.

7. Reichmuth J (1975). Somatic cell counting-Interpretation of results. In: Proc Seminar on Mastitis Control, 7-11 April. International Dairy Federation, Brussels, 85:93- 109.

8. Ruegg PL, Pantoja JCF (2013). Understanding and using somatic cell counts to improve milk quality. Irish Journal of Agricultural and Food Research 52:101-117.

9. Sheldrake RF, Hoare RJT, McGregor GD (1983). Lactation stage, parity and infection affecting somatic cells, electrical conductivity and serum albumin in milk. J Dairy Sci 66:542-547.

10. Smith RD (2006). Veterinary Clinical Epidemiology. 3rd ed, Taylor \& Francis Group, LLC.

11. Węglarz A, Gardzina-Mytar E, Zapletal P, Makulska J, Frelich J (2008). Effect of the parity, lactation stage and season of feeding on the somatic cell count in cow milk. Journal of Agrobiology 25(2):209-214. 